
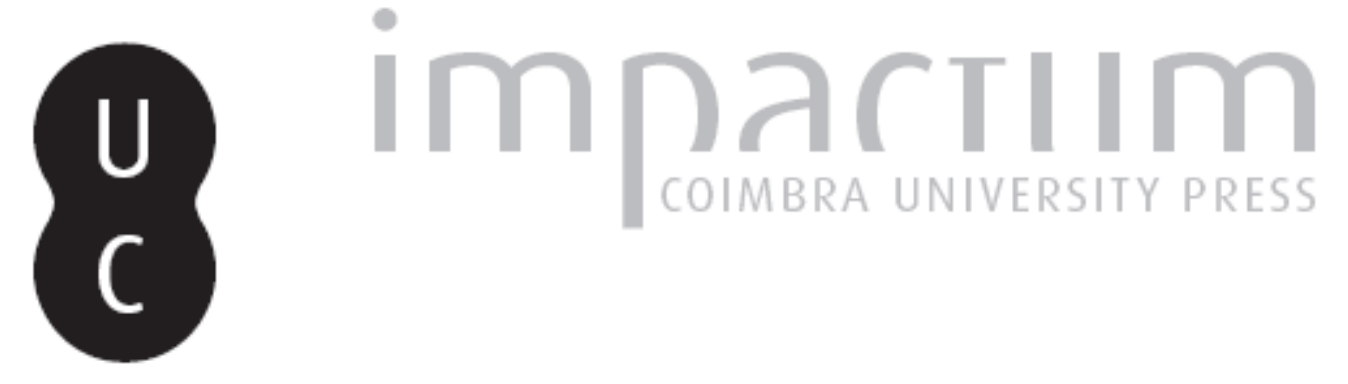

\title{
The rejected versions in Plato's Symposium
}

\section{Autor(es): Luz, Menahem}

Publicado por: $\begin{aligned} & \text { Sociedade Internacional de Platonistas; Imprensa da Universidade de } \\ & \text { Coimbra }\end{aligned}$

URL

persistente:

URI:http://hdl.handle.net/10316.2/36950

DOI:

DOI:http://dx.doi.org/10.14195/2183-4105_14_1

Accessed : $\quad$ 26-Apr-2023 15:07:12

A navegação consulta e descarregamento dos títulos inseridos nas Bibliotecas Digitais UC Digitalis, UC Pombalina e UC Impactum, pressupõem a aceitação plena e sem reservas dos Termos e Condições de Uso destas Bibliotecas Digitais, disponíveis em https://digitalis.uc.pt/pt-pt/termos.

Conforme exposto nos referidos Termos e Condições de Uso, o descarregamento de títulos de acesso restrito requer uma licença válida de autorização devendo o utilizador aceder ao(s) documento(s) a partir de um endereço de IP da instituição detentora da supramencionada licença.

Ao utilizador é apenas permitido o descarregamento para uso pessoal, pelo que o emprego do(s) título(s) descarregado(s) para outro fim, designadamente comercial, carece de autorização do respetivo autor ou editor da obra.

Na medida em que todas as obras da UC Digitalis se encontram protegidas pelo Código do Direito de Autor e Direitos Conexos e demais legislação aplicável, toda a cópia, parcial ou total, deste documento, nos casos em que é legalmente admitida, deverá conter ou fazer-se acompanhar por este aviso.

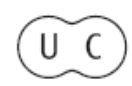




\section{Established 1989}

http://platosociety.org/

\section{Papers}

Menahem Luz,

The Rejected Versions in Plato's Symposium

Anne Gabrièle Wersinger, Le sens de la "kuèsis " dans la perspective des mythes de la gestation

(Banquet 201d-212b)

오

Gabriele Cornelli,

Socrate et Alcibiade

Brad Berman,

The Secret Doctrine and the Gigantomachia: Interpreting Plato's Theaetetus-Sophist

Paul DiRado,

Cephalus, the Myth of Er, and Remaining Virtuous in Unvirtuous Times Aaron Landry, Inspiration and Technē : Divination in Plato's Ion

$<$
$Z$
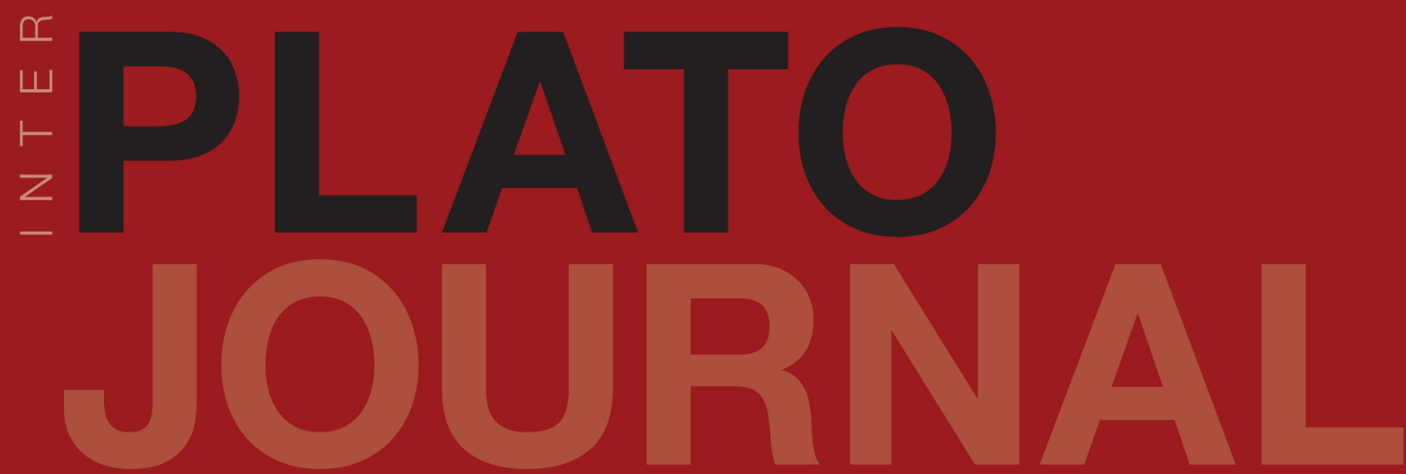

Société Platonicienne Internationale

Associazione Internazionale dei Platonisti

Sociedad Internacional de Platonistas

Internationale

Platon-Gesellschaft

Imprensa da

Universidade

de Coimbra

Coimbra

Universiy

Press 


\section{The Rejected Versions in Plato's Symposium}

\section{Menahem Luz}

University of Haifa, Israel

mluz@research.haifa.ac.il

\section{ABSTRACT}

Apollodorus' prelude to PI. Symp. is a complex rejection of earlier accounts of Socrates' participation in a symposium. This can be examined contextually as a literary mannerism, or sub-textually as a rejection of previous literary versions of this topos. Neither approach contradicts the other, but scholars have found difficulties in finding any earlier author who could have been rejected. Recently, it has been argued that Xen. Symp. preceded PI. Symp. acting as a catalyst for Plato's work. However, if neither was the first on a sympotic theme in a Socratic dialogue, we need not presume that Apollodorus referred to Xenophon, but rather that both responded to an earlier author. Scholars suggest various candidates although none has been proven. However, one source has not attracted attention: two anecdotes recorded in PFlor 113 where Antisthenes depicts both Socrates and himself as critical of symposia in general. The conclusions of my paper are that the contents of these anecdotes can be seen as the raw kernel out of which both Xenophon and Plato could have responded

Keywords : Plato, Xenophon, Antisthenes, sympotic genre, chronological priority 
W.K.C. Guthrie once described the introductory narrative of Plato's Symposium as 'extraordinarily complicated.' ${ }^{1}$ That is to put it mildly as the complexity of its opening pages resembles a set of Chinese boxes each interlaced and set inside its predecessor. There Apollodorus alludes to a multiplicity of differing accounts of Socrates' participation in Agathon's symposium, quite clearly rejecting some in favour of others. In retelling his final version of the event to an unknown companion, he records a previous conversation with his friend, Glaucon, who had also questioned the accuracy of earlier versions: ${ }^{2}$

'For someone else who had heard about it from Phoenix the son of Philip had told me (viz. Glaucon) about it and said that you (viz. Apollodorus) also knew about it for in fact he did not have anything clear to say about it himself'. (172b3-5).

With this Apollodorus agreed:

'I also said, Your narrator does not seem to have given you a clear account of anything of it at all if you think that the meeting took place in recent times'. (b8-c2).

Apollodorus, however, had received a more original account though not from Socrates himself:

'but from the very person who had told it to Phoenix, some Aristodemus or other from the deme of Cydathenaeon [...] and he himself had been present at the meeting [...] nonetheless, I questioned Socrates afterwards about a few things that I heard from the latter and he affirmed that it was as he had related'. (173b1-6)

Here, we can discern four if not five separate layers of narration. ${ }^{3}$ In the following paper,
I shall first discuss viable ways of interpreting these literary maneuvers: first, on a dramatic level as a rejection of solely imaginary versions of the event - and then on a sub-textual level as a rejection of previous versions composed by authors other than Plato. ${ }^{4}$ I will then briefly examine previous suggestions concerning who such rivals authors could have been. Finally, I will reopen the case for considering Antisthenes as an early author in the sympotic genre preceding both Plato and Xenophon, but differing from them in compositional and dialogic style.

\section{CONTEXT AND SUB-TEXT}

If we are to accept Apollodorus' account literally, it would require us to believe that not only a previous version, but a number of previous versions existed prior to his own description of Agathon's symposium. From the point of view of the drama of the situation, all of these were apparently oral accounts. Many scholars have been happy to regard this involved prelude as a mere literary 'mannerism' demonstrating Plato's determination to foreswear any historical reality behind his composition. ${ }^{5}$ However, while not denying that an element of this motive lies behind many of his dialogues and to a great extent also Plat. Symp. itself, this alone does not explain the extraordinary lengths to which he went in the present instance, nor the fact that this is the only case where a character in his dialogues alludes to rival versions of the same conversation. ${ }^{6}$ Were their sole justification a form of literary and historical Distanzierung, the multi-nested preambles of Plat. Symp. would be an act of over-kill even by the author's own standards. In fact, as Apollodorus quite clearly states, some of these versions of the event were blatantly wrong (172b, 173b). We 
are thus dealing not only with an act of dissociation from the veracity of the text, but with a dismissal of alternative versions where Apollodorus is no mere mouth-piece even for Aristodemus' account of the feast since Apollodorus boasts of his fine 'scholarship' in checking the details of the story with Socrates himself (172c, 173b). That the complexity of a multi-layered introduction to Plat. Symp. was a conscious and intentional plan may be seen from the way in which the author develops the introduction's inner logic. Apollodorus' remarks are a prima facie admission that at least two earlier, rival versions were meant to have existed as far as the drama was concerned, but that each was deemed worthy to be dismissed:

1. The rejected faulty version of Phoenix and his unnamed audience;

2. And the first 'version' passed on by Aristodemus later to be collated with Socrates' recollections and related by Apollodorus as a revised version.

Another approach is to understand Apollodorus' introduction not on a dramatic level in reference to imaginary oral accounts of Agathon's symposium, but on a sub-textual level and in reference to rival literary accounts of Socrates' participation in a symposium that, on this hypothesis, are rejected in the opening narration. ${ }^{7}$ Neither explanation necessarily precludes the other in principle since Apollodorus' outburst in the introduction could have simultaneously served as a dramatic backdrop for any philosophical and literary references to be made in a conjectural subtext. However, on the dramatic level, all of the differing versions if not contradictory accounts mentioned by him are meant to refer to one and the same event at the house of Agathon. Formally speaking, any alternative literary accounts implied in the introduction would have had to concern not just Socrates' participation in any symposium whatsoever, but one convened at Agathon's house for that specific celebration. Nonetheless, given that we have Xenophon's totally different treatment of Socrates' appearance at Callias' symposium composed within the same broad era as Plato's composition ${ }^{8}$ - as well as fragments of other writers from that period ${ }^{9}$ - we see that the literary and philosophical topos of describing Socrates' participation in a variety of imaginary symposia was well established during Plato's life time though not necessarily in relation to one and the same event as that hosted at Agathon's house. ${ }^{10}$ However, we should note that the first philosophical use of this topos was confined to a coterie of specific disciples of Socrates and written up during a specific time-period during the first half of the $4^{\text {th }}$ century BC. We are thus speaking of a literary topos that would at any rate have been subject to change, interchange and dispute among those of his disciples who conjured up the philosophy of a sympotic event and the life of the master.

\section{RIVAL COMPOSITIONS}

The debate over whether Apollodorus' remarks should be understood on a sub-textual level in reference to rejected literary versions of different Socratic symposia is thus not necessarily precluded by the previous argument albeit that it still requires objective substantiation. However, any hypothesis that Plato also meant to 'reject' previous literary accounts necessarily assumes that earlier 'rival' versions had existed prior to Plato's composition. Yet, many have naturally assumed from the polish and perfection of his Symposium masterpiece that he was the prime inventor of the genre of 
Socratic symposia. In order to explain common phrases and recurring allusions in the symposia compositions of both Plato and Xenophon, ${ }^{11}$ the traditional view has been to regard Plato not only as 'il miglior fabbro', but also as the original with Xen. Symp. generally regarded as the poorer imitation..$^{12}$ More recently, however, the case for Xenophon's chronological priority and even originality has been defended, sometimes with surprising vigour. ${ }^{13}$

Laying aside arguments based on the subjective evaluation of the originality and priority of either author, we are on surer ground when we attempt to correlate them on the basis of historical evidence. ${ }^{14}$ Most often cited are references made in Xenophon concerning Theban and Eleian military unit(s) based on the lover-beloved principle of the 'Sacred Band' and parallel to a similar idea mentioned in Phaedrus' speech in Plato. ${ }^{15}$ Aside from the issue that Plato no less than Xenophon may be accused of introducing into a Socratic conversation anachronistic references to military units that were organized on this principle only after $379 / 8$ $\mathrm{BC}$, the nature of their correlation lies in the details of their description. ${ }^{16}$ Xenophon refers to the existence of these units as an historical reality albeit in a Socratic dialogue:

'Yet Pausanias, the lover of the poet Agathon, defended those who wallow in lack of self control, saying that even a military unit would also prove most valiant if it were comprised of lovers and beloveds! For, in his opinion, he said, these would be at any rate ashamed to desert one another [...] and he also adduced proof from the Thebans and the Eleans who would acknowledge this while, he claimed, that though they slept with their beloveds, the latter were nonetheless marshalled alongside them in the fray'. (Xen. Symp. 32-34).
By contrast, Plato's character Phaedrus describes a similar unit only as a theoretical possibility still yet to be actualized - and thus makes an anachronistic slip only implicitly:

'If then there could be some means for a city or an army to be comprised of lovers and beloveds, then it would be impossible for them not to manage a city better for they would abstain from all shameful deeds while at the same time esteeming one another - and were they to do battle alongside one another, such (troupes) would vanquish almost all men even when few in numbers. I assume, therefore, that a manly lover would be less given to break rank or throw away his weapons in the sight of his beloved more than before all other men - and would often thus chose to give up his own life'. (Plat. Symp. 178e).

Dover followed, by many other scholars, reasonably concludes that we should give Plato's work a date prior to the actual establishment of these units whereas Xenophon's recognition of their reality should be dated to sometime afterwards. ${ }^{17}$ On the other hand, those who still insist on predating Xen. Symp. to Plat. Symp. have to explain allusions in the former reflecting Platonic dialogues written subsequent to it. ${ }^{18}$ They are thus obliged to speculate on the publication of Xen. Symp. in two editions: an earlier one supposedly provoking Plato into producing his own Symposium in the late 380 's - and a later one incorporating substantial changes in response to Plato and presumably written in the 370 's sometime after the organization of the 'Sacred Band'. ${ }^{19}$ Consequently, these scholars conclude that the butt of Apollodorus' rejection of previous descriptions of Socrates' participation in a symposium was 
really a shorter first edition of Xenophon's work that served as a catalyst for Plato's decision to write a composition of this type at all. Since our present Xen. Symp. viii-ix conflates and also responds to the speeches ascribed to Phaedrus and Pausanias (Plat. Symp., 178a-180b, $180 \mathrm{c}-185 \mathrm{c}$ ), they suggest that those chapters were added later in a revised edition of this work written after the historical formation of the 'Sacred Band' in 379/8 BC. ${ }^{20}$ In this edition, it is argued, Xenophon deliberately questions the morality of the speeches formulated in Plato's intervening works. ${ }^{21}$

Many scholars have been reluctant to accept many of these complicated conjectures, ${ }^{22}$ but even granted the possibility of a revised edition of Xen. Symp., there is no direct proof that an earlier edition was what inspired Plato to compose a sympotic dialogue. ${ }^{23}$ For the present paper, however, it is not at all required that a final choice be made between either theory when we examine whether there could have been a philosophical precedent for the works of both Plato and Xenophon to which either was likely to respond. If such a precedent existed prior to Plato's composition, it would not be necessary to assume that he was replying to Xenophon whether we consider the latter to precede him or not. Although older scholars considered the possibility of a yet earlier philosophical work in this genre a serious issue, supporters of Xenophon's originality have denied that there was any description of a dialogic symposium associated with the Socratic circle prior to Xenophon's own composition. ${ }^{24}$ Nonetheless, over the years, various attempts have been made to identify some earlier author who could have served as the butt of Plato's references whether or not he also served as a source for Xen. Symp. as well. ${ }^{25}$ However, those scholars who admit that Apollodorus' remarks are an implicit rejection of an earlier sympotic com- position are in no way agreed even concerning the question: to which author(s) Plato would have likely referred? With the controversy over the likelihood of Xenophon examined above, two other hypotheses can be discarded more briefly:

1. Bury suggested Plato's contemporary, the sophist Polycrates, who was notorious for his attack on Socrates' memory and his criticism of the latter's relationship with Alcibiades. ${ }^{26}$ However, while the section describing Alcibiades' participation in the Symposium could well contain elements of a reply to Polycrates' fictitious Categoria of Socrates, the sophist's speech could not serve even as a rhetorical precursor for Plato's dialogic composition and is unlikely to have passed as a symposium with or without Socrates and Alcibiades. ${ }^{27}$ Thus, without denying the position that Polycrates occupied in Plato's 'black book', his writings could not be described as a rival version of Socrates' participation at a symposium that regularly circulated among Socrates' companions as is implied in Apollodorus' preamble.

2. The same may be said of the dialogues of Aeschines of Sphettus. Latterly, it has been suggested that his theory of Socratic eros was both original and innovative in its time influencing both Plato and Xenophon. ${ }^{28}$ Yet, while not gainsaying Aeschines' philosophical importance, the fragments of his dialogues do not indicate a sympotic gathering in any way. Aeschines is thus unlikely to be intended by Apollodorus as one who circulated an account of Socrates' participation in a symposium even though Aeschines' 
Alcibiades and Aspasia dialogues were likely to have been read by both Plato and Xenophon while authoring their own compositions.

While the last two candidates are unlikely objects of Apollodorus' rebuttal, the case for Antisthenes is somewhat stronger. Although he is not named in Plat. Symp, he is a major participant in Xen. Symp. ${ }^{29}$ Furthermore, he was a Socratic thinker said to be directly involved in philosophical disputes with Plato himself (DL VI. 7-8). An older theory thus saw his lost Protrepticus as somehow fulfilling a role in this respect. ${ }^{30}$ This composition is listed as part of a series of discussions on the moral virtues apparently belonging to the same period as the Symposia of Plato and Xenophon. ${ }^{31}$ From its meager fragments we may gather that it was a work in dialogic form, possibly sympotic in character and featuring Socrates as a conversant. ${ }^{32}$ However, evidence for its sympotic character is limited to a single late tradition: a reference to the $\beta o \mu \beta v \lambda$ ıó ('wine-sipping' jug) whose 'form' and 'Idea' were discussed in Antisthenes' Protrepticus. ${ }^{33}$ Obviously, this is not sufficient proof in itself that the latter was sympotic rather than simply a discussion of sympotic accessories. However, whether or not the Protrepticus was sympotic itself, more compelling evidence for some composition written by Antisthenes in this genre has been overlooked in this context.

\section{ANTISTHENES AS AUTHOR OF A SYMPOTIC DIALOGUE}

The $2^{\text {nd }} C E$ Papyr. Flor. 113 preserves large sections of a lost, partly sympotic, dialogue concerning success and failure in the arts, sciences and philosophy. ${ }^{34}$ It is part of this context that two obviously parallel anecdotes are related. Each describes a philosopher who failed to influence his pupil when absent from his presence at some sort of deipnic event. ${ }^{35}$ The first anecdote records a conversation held between Socrates and a critic concerning his failure to make Alcibiades a better person in spite of his lengthy study under him for what Socrates 'would teach him by day, others unravel it at night', presumably at some social coterie: ${ }^{36}$

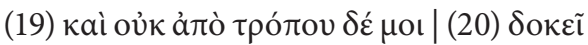

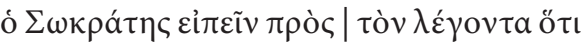

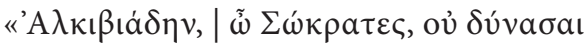

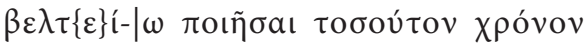

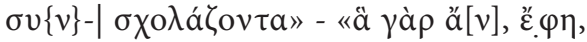

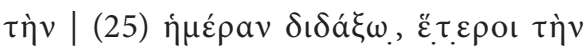

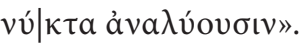

The composition immediately continues with a similar report concerning Antisthenes that a favourite of his was being successfully feted by rivals out 'to catch him' with a fish dinner. In reply, the philosopher claimed that that is no naval victory for them: 'I am indeed not beaten at sea for the lad may think that it is worth requesting (fare) like that, but I am a person who withdraws from those sort of things'. ${ }^{37}$

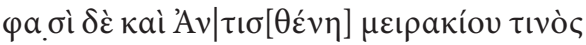

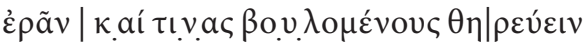

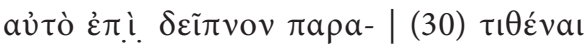

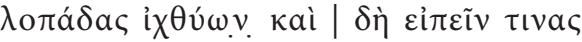

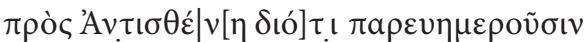

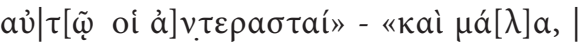

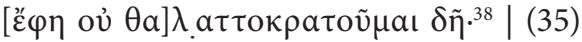

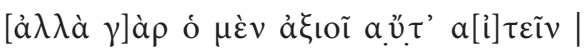

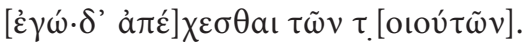

In regards to their presentation, these anecdotes purport to be vignettes of two separate 
philosophical conversations: one held between Socrates and an unnamed critic - and the other between Antisthenes and unnamed friends. However, the anonymous author of Papyr. Flor 113 regards them as a single, continuous and unbroken argument. ${ }^{39}$ If we first compare them structurally and then conceptually, we will indeed find that the anecdotes comprise a philosophical unity.

Structurally, both describe a philosopher who has been informed only indirectly of a pupil's participation in a detrimental social event. ${ }^{40}$ In each case, the philosopher had vied with rivals for the attention of that pupil, but failed to inculcate his moral teaching when the pupil had been seduced into participating in it. Thus, when Socrates explains why he had proved incapable of making Alcibiades 'a better person', he compares the situation to that of Penelope and the rival suitors of the Odyssey: others unravel the web of his (viz. Socrates') day-time teaching by night. ${ }^{41}$ In the second anecdote, it is explicitly stated that those who tried to seduce the lad with a fish dinner were

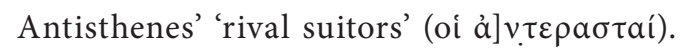
It is true that, in the case of Alcibiades, it is not specifically stated that he slipped away to attend a deipnon as in the case of Antisthenes' favourite. However, since Alcibiades is said to have met 'others' (in the plural) at night, the anecdote imagines him participating in a sympotic-like meeting with a number of suitors (erastai) rather than in an assignation with a particular person alone. ${ }^{42}$ Conceptually, we also find the same presuppositions and argument in both anecdotes. Socrates admits that he taught $(\delta\llcorner\delta a ́ \xi \omega$.$) Alcibiades previously and since the$ latter had not become 'a better' person $(\beta \varepsilon \lambda \tau\{\varepsilon\}$ $i-\mid \omega)$, we may infer that part of this teaching was in respect to moral themes. Furthermore, since Socrates specifically employed the allegory of Penelope's web, this must have touched on some aspect of eros, faithfulness and self-restraint, to be later undone by Alcibiades' participation in nocturnal tryst(s) with suitors of his own. In Antisthenes' case, there is criticism both of the deipnic event itself and also of its influence on the lad's moral values, here contrasted with his own: the lad considered these feasts

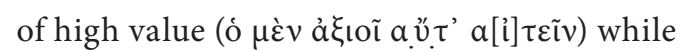
Antisthenes would personally withdraw from the likes of them $\left(\left[\dot{\varepsilon} \gamma \omega^{\prime} \cdot \delta^{\prime} \dot{\alpha} \pi \dot{\varepsilon}\right] \chi \varepsilon \sigma \theta \alpha \mathrm{l} \tau \tilde{\omega} \nu\right.$ $\tau$.[oเovi $\tau \tilde{\omega} v])$. Moreover, since the anterastai at least partially 'succeeded' with the lad - it can be argued that Antisthenes was critical not just of the lad's consent to a sympotic dinner, but also to their erotic overtures. ${ }^{43}$ Although it is not stated that he had previously attempted to teach him moral values as said of Socrates and Alcibiades previously, it must be surmised from Antisthenes relationship as his previous erastes that he had ample opportunity to do so - and, as a Socratic philosopher, would have been expected to do so. ${ }^{44}$ If these conclusions are correct, then both anecdotes also have the same philosophical purpose: the teaching of moral values, specifically self-restraint, but also the failure of a Socratic philosopher to instill it in certain pupils. Their unity of structure and philosophy would thus suggest that both anecdotes derive from the same tradition if not the same source. ${ }^{45}$ There both Socrates and Antisthenes feature in a reference to some deipnic/ sympotic gathering, but do not participate in it personally. Each philosopher criticizes the spirit of such a gathering as counter to his teaching. They thus both exemplify the failure of philosophical (viz. Socratic) eros to inspire virtue in a 'failed' pupil who had been seduced by such events. ${ }^{46}$

This construction clearly differs from that of our surviving Symposia. In Xenophon, both Socrates and Antisthenes feature as active participants with the emphasis placed on the 
success of Socrates' philosophy of education accomplished through eros particularly in the discussion between Socrates and Antisthenes himself (Symp. IV. 42-44, VIII 5-6). In Plato, of course, Socrates is even more of a key figure in the drama, but one whose philosophy of eros is depicted not just as an apparent success - at least in the eyes of his many disciples (Symp. 173b-c) - but also as a failure in the case of Alcibiades (212c-215a, 216d-218e) ${ }^{47}$ Moreover, in one further characteristic, the account in our papyrus anecdotes belongs to a completely separate treatment of this theme: not only are Socrates and Antisthenes absent from the deipna themselves, but the atmosphere of the latter were obviously not meant to be conducive to philosophical discussion. In fact, their spirit is explicitly described as counter to it. By contrast, the works of Plato and Xenophon in this genre have Socrates transform the sympotic deipnon into a more worthy place for philosophical discussion rather than stand outside of it in criticism.

The relationship between these traditions is no accident. It should not be forgotten that in addition to its narrative and gnomic value concerning Antisthenes and his milieu, the second anecdote has long been accepted in standard collections of Antisthenes' fragments as at least indirectly derived from his lost dialogues if not an actual extract from one of them. ${ }^{48}$ This is also apparent from its argumentation concerning: the mistaken value of luxury ( $l l$. $34-35)$, the role of eros in education $(26,33,35)$, philosophical abstinence (36), and the moral invulnerability of the true philosopher (34). ${ }^{49}$ Furthermore, if we accept that the criticism in the anecdote is aimed at the lad's indiscretions with the erastai no less than his eagerness to join their deipnon, then its assumptions concerning karteria and self-restraint recall topics widely ascribed to Antisthenes himself. ${ }^{50}$ This is true despite Antisthenes' personal appearance in the second anecdote where he would have to be imagined speaking in persona. From what we learn from his fragments, his dialogues were indeed interrupted by personal remarks made by the author himself ('Antisthenes said' or 'I myself saw'). ${ }^{51}$ While this may generally recall the more personal style of Xenophon when re -handling his own Socratic material rather than that of Plato, Xenophon is not so much a direct participant in his Symposium but speaks as one who introduces it, or presents it to the reader. ${ }^{52}$ Some, moreover, have also found key concepts and metaphors associated with Antisthenes' philosophy in the discussion of the first anecdote as well. ${ }^{53}$ In addition to its general character as a Socratic dialogue critical of Alcibiades' sexual habits, the specific cento on Penelope's web is well within the context of Antisthenes' catalogued works. ${ }^{54}$ We have already seen how both anecdotes have a unity of philosophical and dramatic purpose, so that it is not surprising that Antisthenean philosophical notions have been associated with the first anecdote as well. Nonetheless, whatever conclusions we draw concerning the Antisthenean origin of the latter, it is unlikely to have referred to the same event as the second anecdote. The two must refer to two imaginary, but separate symposia/deipna: Alcibiades' nocturnal coterie and the deipnon attended by Antisthenes' friend. ${ }^{55}$ This in itself does not necessarily contradict the hypothesis that both are derived from the same source since it is well known that Antisthenes' writings were episodic in structure often composed of short dialogic vignettes. ${ }^{56}$ At any rate, even if we accept only the second anecdote as derived from the works of Antisthenes, it is in itself a short vignette and was unlikely to have been much longer in its original. As such, its construction does not rival or even take into account the more complete and dramatically 
complex works written in this genre by Plato and Xenophon. There is thus the distinct possibility that Antisthenes' sympotic vignette(s) preceded their more polished compositions as the rough diamond out of which this topos was reset. As conjectural as this may seem, it may perhaps be also surmised from the single historical reference made in the second anecdote that needs to be re-examined in this context. In response to the story about the fishy dinner with his rival suitors, Antisthenes uses the highly unusual passive form 'I am beaten at

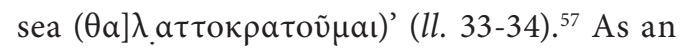
expression, it is known only from a fragment of the comedy, Sicily (or The Sicilians), attributed to the late fifth century dramatist, Demetrius (I) - they (the Spartans) 'could no longer be

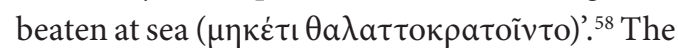
latter referred to Athens' naval concessions to Sparta in 404 BC as well as to the loss of her navy and destruction of her walls mentioned in the previous lines. Recent scholars have thus understood the reference in our second anecdote as an Antisthenean parody. ${ }^{59}$ However, if the play was presented shortly after the restoration of democracy at the end of $403 \mathrm{BC},{ }^{60}$ for Antisthenes' cento to be clearest to his readers, his reference to such a specific line in a lesser known comedy would work best before rather than after the suggested dates for the Symposia of Plato and Xenophon (385/4-378 BC).

If this is the case, then we can understand why Apollodorus' prelude to Plat. Symp. (172$173 \mathrm{~b}$ ) is a rejection of previous accounts of Socrates' criticism of sympotic events. He will give a 'detailed' account of the latter's participation in one (173b), where Socrates turns such an event into a positive and philosophical discussion (c). Thus, Plato's dramatization is not only more polished and complex than that of Antisthenes, but also allows Socrates to turn a symposium into a philosophically educative meeting. In both, the eros of the philosopher is the starting point of education - and in both there is an account of a pupil who fails to be worthy of him once outside his immediate influence. Whatever we conclude concerning Antisthenes' role as an author of a composition on this theme, Apollodorus' rejection of previous accounts of a Socratic symposion is ostensibly aimed at previous treatments of this topos including some presumably circulating at least orally in the Socratic circle. In this respect, Xenophon's contribution is no less interesting. In contrast to our two anecdotes, he is interested in depicting Socrates 'at play' (Symp. I. 1) and participating in such social events. While he has Plato's compositions before him in at least one edition, his award of an active place for Antisthenes in his work utilizes the latter's written philosophy for his account of him, while ironically turning him into an active participant in a philosophical symposium of his own (IV. 34-44, VIII.4-6). It is at least feasible that Antisthenes' criticism of anti-philosophical symposia can be seen as the raw kernel from which the two later authors reworked this topos in the particular way they did.

\section{BIBLIOGRAPHY}

Bluck 1964: R.S. Bluck, Plato's Meno Edited with Introduction and Commentary, Cambridge University Press, Cambridge 1964.

Brancacci 2004: A. Brancacci, 'Il contributo dei papiri alla gnomica di tradizione cinica' in M.S. Funghi (ed.), Aspetti di Letteratura Gnomica nel Mondo Antico II, Firenze 2004, 221-248.

Brandwood 1999: L. Brandwood, Stylometry and Chronology, in R. Kraut, The Cambridge Companion to Plato, Cambridge University Press, Cambridge 1999, 90-120.

Brisson 2006: , L. Brisson, 'Agathon, Pausanias, and Diotima in Plato's Symposium: Paiderasteia and Philosophia, in J.H. Lesher - D. Nails - F.C.C. Sheffield (ed.), Plato's Symosium Issues in In- 
terpretation and Reception, Harvard University Press, Harvard - London 2006, 229-251.

Bury 1973: R.G. Bury, The Symposium of Plato Edited with Introduction, Critical Notes and Commentary, Cambridge 1973.

Chernyakhovskaya 2014: O. Chernyakhovskaya, Sokrates bei Xenophon Moral-Politik-Religion, Tuebingen 2014.

Clay 1994: D. Clay, 'The Origins of the Socratic Dialogue' in P.A. Vander Waerdt (ed.), The Socratic Movement, Cornell University Press, Ithaca-London 1994.

Comparetti 1910: D. Comparetti (ed.), Papiri letterari ed epistolari (Milan, 1910), in D. Comparetti - G. Vitteli (ed.), Papiri greco-egizii pubblicati dalla R. Academia dei Lincei II, Ulrico Hoepli, Milan 1908-1911.

Corrigan 2004: K. Corrigan - E. Glazov-Corrigan, Plato's Dialectic at Play Argument, Structure, and Myth in the Symposium, Pennsylvania State University Press, Pennsylvania 2004.

Croenert 1908: C. (= W. Croenert), 'Sprachkunde, Literarturgeschichte: Papiri Letarari ed epistolari per cura di Domenico Comparetti Fasc I no. 106-11', «Deutsches Literarisches Zentralblatt» 59 (1908), col. 1199-1202.

Danzig 2005: G. Danzig, 'Intra-Socratic Polemics: The Symposia of Plato and Xenophon', «Greek, Roman and Byzantine Studies» 45 (2005), 331357.

Decleva-Caizzi 1966: F. Decleva-Caizzi, Antisthenis Fragmenta, Edizioni Cisalpino, Milano 1966.

Dodds 1985: E.R. Dodds, Plato Gorgias A Revised Text with Introduction and Commentary, Oxford University Press, Oxford 1985.

Dornseiff 1940: F. Dornseiff, ,Zeitbestimmung von Platons Symposion durch Xenophon', 77 (1942), 112.

Dorion 2011: L.-A. Dorion, 'The Rise and Fall of the Socratic Problem', in D.R. Morrison (ed.), The Cambridge Companion to Socrates, Cambridge University Press, Cambridge 2011, 1-23.

Dover 1965: K. J. Dover, 'The Date of Plato's Symposium', «Phronesis» 10.1 (1965), 2-20.

Dover 1980: Sir K. Dover, Plato Symposium, Cambridge University Press, Cambridge 1980.

Funghi-Caizzi 1999: M.S Funghi,. - F.D. Caizzi, 'Socrates 2T', Corpus dei papiri filosofici greci e latini $(C P F)$, vol $1^{* * *}$, Leo S. Olschki Editore, Firenze 1999, 718-720.

Gallo 1980: I. Gallo, Frammenti Biografici da Papiri
II La biografia dei filosofi, Edizione dell'Ateneo \& Bizarri, Roma 1980.

Goulet-Cazé 1999: M.-O. Goulet-Cazé (ed), Diogène Laërce Vies et Doctines des Philosophes Illustres, La Pochothèque, Paris 1999.

Guida 1989: A. Guida, '18 Antisthenis* 2T', Corpus dei papiri filosofici greci e latini (CPF), vol.. $1^{*}$ Leo S. Olschki Editore, Firenze, 1989, 238-240.

Gera 1993: D.L. Gera, Xenophon's Cyropaedia Style, Genre, and Literary Techinique, Oxford Clarendon Press, Oxford 1993.

Guthrie 1975: W.K.C. Guthrie, A History of Greek Philosophy IV, Cambridge University Press, Cambridge 1975.

Hindley 2004: C. Hindley, 'Sophoron Eros: Xenophon's Ethical Erotics', Christopher Tuplin (ed.), Xenophon and His World Papers from a Conference Held in Liverpool 1999, Franz Steiner Verlag, Stuttgart 2004, 125-146.

Huss 1999: B. Huss, Xenophons Symposium Ein Kommentar, B.G. Teubner, Stuttgart-Leipzig 1999.

Joël 1901: K. Joël, Der Echte und der Xenophontische Sokrates II 2, R. Gaertners Verlagsbuch, Berlin 1901.

Kahn 1994: C. H. Kahn, 'Aeschines on Socratic Eros', in P.A. Vander Waerdt (ed.), The Socratic Movement, Ithaca-London: Cornell University Press 1994, 87-106.

Kahn 1998: C. H. Kahn, Plato and the Socratic Dialogue The Philosophical Use of a Literary Form, Cambridge University Press, Cambridge 1998.

Koerte 1920: A. Koerte, 'Anonyme Diatribe', «Archiv fuer Papyrusforschung» 43 (1920), 239.

Ledger 1989: G.R. Ledger, Re-Counting Plato A Computer Analysis of Plato's Style, Clarendon Press, Oxford 1989.

Luz 1996: M. Luz, 'Antisthenes' Prometheus Myth', in J. Glucker - A. Laks (ed.), Jacob Bernays un philologue juif, Presses Universitaires du Septentrion, Villeneuve d'Ascq 1996, 89-103.

Luz 2014: M. Luz, 'The Erlangen Papyrus 4 and its Socratic Origins', in, «JPT» 8 (2014), 161-191.

Luz 2015: M. Luz, 'Socrates, Alcibiades and Antisthenes in PFlor 113', in Ugo Zilioli (ed.), From the Socratics to the Socratic Schools: Classical Ethics, Metaphysics, and Epistemology, N.Y.-Oxford 2015, cap. 11 .

Nails 2002: D. Nails, The People of Plato A Prosopography of Plato and Other Socratics, Hackett Publishing Company, Indianapolis-Cambridge 
2002.

PCG: R. Kassel, - C. Austin (ed.), Poetae Comici Graeci V Damoxenus - Magnes, Walter De Gruyter, Berlin-N.Y. 1986.

Prince 2015: S. Prince, Antisthenes of Athens Texts Translation and Commentary, University of Michigan Press, Ann Arbor 2015.

Rosen 1968: S. Rosen, Plato's Symposium, Yale University Press, New Haven-London 1968.

Rowe 1998: C. J. Rowe, Plato: Symposium Aris \& Phillips, Warminster 1998.

SSR: Gabriele Giannantoni, Socratis et Socraticorum Reliquiae II, Bibliopolis, 1990.

Storey 2011: I.C. Storey (ed. trans.), Fragments of Old Comedy Alcaeus to Diocles I Loeb Classical Library, Harvard 2011.

Thesleff 1978: H. Thesleff, 'The Interrelation and Date of the Symposia of Plato and Xenophon', «Buletin of the Institute of Classical Studies» 25 (1978), 157-170.

von Fritz 1935: K. von Fritz, ,Antisthenes und Sokrates in Xenophons Symposion', Rhein. Mus.» 4 (1935), 19-45.

Waterfield 1999: R. Waterfield, 'Xenophon and Socrates', in C. Tuplin (ed.), Xenophon and His World Papers from a Conference Held in Liverpool 1999, Franz Steiner Verlag, Stuttgart 2004, 79-113.

Wohl 2002: V. Wohl, Love Among the Ruins The Erotics of Democracy in Classical Athens. Princeton University Press, Princeton-Ox. 2002.

\section{NOTES}

1 Guthrie 1975, 366. I would like to thank Prof. Susan Prince for enabling me to use proofs of her edition of Antisthenes' fragments. In the following, all translations are my own.

2 It is a moot question whether this Glaucon is meant to be identified with Plato's older brother of that name (Rowe 1998, 127; Nails 2002, 154 ('Glaucon IV’), 154-156, 314).

3 1. The original account related by Aristodemus to Apollodorus and Phoenix (Symp. 173 b1); 2. that given by Phoenix to an unknown source (172 b); 3. that source's garbled redaction passed on to Glaucon and company (172 c3-6); 4. Apollodorus' own 'researched' version describing the drama set out in the written dialogue. Moreover, if this Glaucon is Plato's brother (above, n. 2), from a sub-textual point of view, he could be supposed to be Plato's immediate source for the events in the written dialogue. It could thus be plausibly argued that we distin- guish between the dialogue as orally narrated to Glaucon by Apollodorus and: 5. Glaucon's possible report of this to Plato. However, for the following argument, this last option can be ignored.

$4 \quad$ Although we know of an historical basis for Agathon's dramatic victory in $416 \mathrm{BC}$ plausibly entailing a symposium hosted by him (Dover 1980, 8-10), my discussion relates only to its imaginary treatment in Socratic literature.

5 Cf. Rowe 1998, 127 (that Plato aims at verisimilitude and explanations of the polished nature of his account); Corrigan 2004, 7-12 (either as a means to distance his account from any claim of historic accuracy - or as a means to conjure up the Socratic spirit and the interest in late $5^{\text {th }}$ century Athens); Rosen 1968, 12-16 (to draw out the comparison of the Symposium with the Republic).

6 The introduction not only envelops four versions of the same conversation (above, n. 3), but is also multi-layered, dramatizing a conversation held with Glaucon, that simultaneously unfolds a revised version of Aristodemus' account. Other dialogues are much simpler, comprising two-fold accounts: the relation of Plat. Phaid. with its opening and closing addresses to Echecrates (57a-59c, 117b-118a), Theaetet. opening as a conversation held between Euclid and Terpsion (142a-143c) though based on notes made of Socrates' conversation with Theodorus and Theaetetus (143d-210b) and Parm. opening with a preamble on how Socrates' conversation came to be recorded and transcribed (126a-127d).

7 See the scholars noted in Thesleff 1978, 167168, but latterly in: Huss 1999, 14 n. 5; Danzig 2005, 331. $8 \quad$ Laying aside for the moment the question of the 'inter-relationship' of Plato and Xenophon and the exact dates of their compositions (Huss 1999, 13-15, 1618 ), both works belong to the 1 st half of the 4 th century whichever of the two was prior.

9 Scholars suggested Antisthenes' Protrepticus (SRS II VA fr 63-67, 175), but there is further evidence to be examined below.

10 Scholarship adopts a similar view of Xenophon's imaginary and inventive account of Callias' symposium (Huss 1999, 18-24) even though ostensibly introduced by himself (Symp.I.1-2).

11 Setting aside speculation on general responses of either to the other (Waterfield 2004, 98-107; Dornsteiff 1942, 112; von Fritz 1935, 20-21, 43-45), linguistic and philosophical comparisons have be made between specific passages (107-110), and importantly their Symposia: Thesleff 1978, 158-163 (disc. pp. 164-168) and Huss 1999, 449-455 (disc. pp. 13-55), who compare Xen. Symp. viii 1-39, IX 1, 7 to Plat. Symp. (172-178, 185c, 190a, 213), Phdr. (239c-240d. 251d-254a).

12 Cf. Huss 1999 on Plato' chronological priority and literary genius in contrast to such a 'mittelmaesigen Autor' as Xenophon (14-15) who at the best composed a later 'pastiche' out of bits and pieces of various dialogues and other Socratic writers (18) - or as a 'bit of a plodder' in contrast to Plato (Waterfield 2004, 79-80). More recent 
opinion has somewhat toned down this judgment of Xenophon's lack of innovation (Chernyakhovskaya 2014, 6-7) although this does not dispute his borrowings from a variety of authors, particularly Plato, Antisthenes and Aeschines.

13 Aside from the chronological issue (Thesleff $1978,167-168$ on the priority of Xen. Symp.), more recent scholars see this as part of a reciprocal process involving the influence of not only Xen. Symp. on Plato but also Xen. Mem. (Danzig 2005, 348 n. 42). A more balanced appraisal of Xenophon's recreation of Socrates in: Chernyakhovskaya 2014, 4-7.

14 Esp. Dorion 2011, 1-23 (on Xenophon's innovative ability in his dramatizations); Danzig 2005, 340 (Xenophon as a more diverse innovator while Plato was 'exclusive' composing only speeches and dialogues). 15 Xen. Symp. viii. 32-35; Plat. Symp. 178e-179b. The former mistakenly ascribes them to Pausanias rather than Phaedrus (Danzig 2005, 331-357), but the reference is similar (Hindley 2004, 347).

16 See esp. Brisson 2006, 236-238 \& n. 44; Nails 2002,222 . There are further anachronisms in Plat. Symp. (Dover 1980, 10) and Xen. Symp. (Anderson 1974, 66 n. 1). 17 Dover 1965, 12-15: while dating Plat. Symp. 193 by reference to Mantineia raises 'problems', the historicity of the Sacred Band is 'firmer ground' for a date of 385/4-378 BC (also Dover 1980, 10). Other 'echoes' of Plat. Symp. in Xen. Symp. in: Huss 1999, 449-453 (appendix of parallel refs.); Waterfield 2004, 109-110.

18 Although the stylometry and chronology of Plato's dialogues are still vacillating problems, the dating of the Phaidr. as subsequent to Plat. Symp, is still widely upheld and reaffirmed by computer analysis (Brandwood 1992, 113-115; Ledger 1989, 209-210). Huss 1999, 453-455 lists detailed passages in Xen. Symp. viii parallel to Plat. Phaidr. 238-241, 252, 256; Kahn 1998, 393-401 lists parallel throughout Xenophon.

19 In his analysis of Xen. Symp. VIII as a revised rebuttal of Plato, Danzig 2005, 331-357, expands on the arguments of Thesleff 1978, 167-168 denying Xenophon's use of Platonic compositions outside Symp. and Phaidr. On the other hand, von Fritz 1935, 44 sees Plato as beyond Xenophon's understanding with the simpler dialogues of Aeschines as much closer to him.

20 Even those who accept the hypothesis of a multi-layered Xen. Symp., do not all accept its priority to Plato (Hindley, 2004, 141\& n. 59), but insist on the structural unity of Xen. Symp. as contradicting its appearance in two editions with the difference between caps. I / VIII explained by the extent to which Xen. relied on Plat. Symp. when constructing it (Huss 1999, 14 \& n. 6).

21 That Xenophon's discussion of paiderastaia is a deliberate 'sanitization' of Plato's discussion, see: Danzig 2005, 331-357; Kahn 1998, 400; Dornseiff 1942, 112.

For an earlier contrary argument, see: Hindley 1994, 348349 , who finds in Xenophon's works less 'rigorist views' of the erastes-eromenos principle even in military affairs, while the solution in von Fritz 1935. 22-23 is to emphasize the discrepancy between teaching and action.
22 Huss 1999, 17-19 sees Xenophon as merely conflating whatever passages he found in his library; and Dover 1965, 14 describes him as 'a creative writer' drawing on whatever material he found.

23 Whatever we think of Xenophon's innovations in historiography and of his contribution to literature (above, n. 14), Huss is correct to judge his philosophical writings as 'pastiche' (above, n. 12). Although Danzig has argued for Xenophon's philosophical response to Plato's Symposium (above, n. 21), this is in reference to his conjectured second version and not to the hypothetical first shorter edition to which Plato is here supposed to reply and where it is claimed that he imitates Xenophon's sympotic framework.

24 Thesleff 1978, 158 basing himself on Athen. V 216 c-f (c. 56) that no other composer of a dialogic symposium in the Socratic genre existed before Xenophon and Plato although in actual fact Athenaeus merely states that Xenophon created Pausanias' speech on paidika (216c) whose details are not in Plato nor any known work of Pausanias (f). Latterly, Danzig 2005, 335 understood that Athenaeus also hints at two editions of

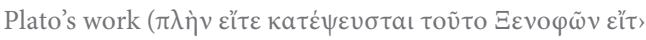

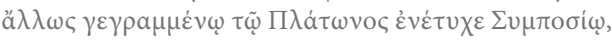
$\pi \alpha \rho \varepsilon i \sigma \theta \omega)$.

25 See: Huss 1999, 13 n; Giannantoni SSR IV 1990, nota 30 (pp. 285-294). Obviously, there was a long tradition of descriptions of literary symposia (Gera 1993, 139, 152-154), but we are here speaking of the 'Socratic' symposium and the contribution of 'Socratic' writers to that specific genre (Dover 1965, 15-16).

26 See Bury 1973, xvii- xix. However, Polycrates' choice of style was set rhetorical pieces, not dialogue like the Symposium (Nails 2002, 252-253).

27 On the arguments for/against his influence on Plato and Xenophon, see: Dodds 1985, 28-29; Kahn 1994, 105-105. On sections of the Symposium recalling Polycrates, see also: Rowe 1998, 136.

28 Kahn 1994, 30-32, 87, 89-94; on Aeschines and Plato's Men., see: Bluck 1964, 117-120; on Aeschines and Xenophon: von Fritz 1935, 43-44.

29 His extended speeches in Xenophon (Symp. IV. 34-44, VIII.4-6) 'affinity' with the depiction of Socrates’ self-restraint (karteria/enkratia; Kahn 1998, 30-32. 30 SSR II 1990, VA 63-67; on the older theories see: Giannantoni in SSR IV 1990, 290-294.

31 Dated alongside Gorgias' Helena, Isocr. Ad Nicol. 39, 45-46 and Xen. Symp. and Plat. Symp. (Giannantoni in SSR IV 1990, 290-294), it was part of a series: 'On Justice and Courage, Protrepticus I-III, On Theognis IV-V' (DL vi. 14). On the series, see: Prince 2015, 44, 123, 137-139; Goulet-Cazé 1999, 695 n.5; Giannantoni ibid. 285-286, 288.

$32 \quad$ Prince 2015, 244, 336, 386 (that at least part of it is to be characterised as sympotic), 63, 244-245 (that Socrates was one of the speakers).

33 On the Protrepticus and the jug's eidos see: Poll. 6. 98, 10. 98-99; vet. schol. in Apoll. Rhod. II 56970 (SSR II 1990, VA 64); on its idea in Athen. xi.784d 
(from an unspecified Socratic dialogue without ref. to Antisthenes or the Protrepticus). Xen. Symp. II. 26 has been compared (SSR II 1990, VA 67; Prince 2015, 244-250; Huss 1999, 170).

34 Papyr. Flor. $113=$ Mertens - Pack $^{3}$ no. 2584 , last edited in: Comparetti 1910, no. 113 pp. 19-26. Misinterpreted as a dialogue (or dialogic diatribe) de suadendo (Croenert 1908, col. 1201; Koerte 1920, 23), the section on philosophical persuasion is just one analogy closing a detailed discussion of success and failure in medicine and the arts (col. I-II). Although the latter does not indicate the dramatic context, the continuation in col. III 12-13 is a moralising discussion of/at some sympotic event (Luz 2015, 312).

35 Gallo 1980, 229-235; SSR II VA fr 175; Guida 1989, no. 18 2T; complete text and translation in: Luz 2015, 197-198.

36 col. II ll. 19-26; Funghi - Caizzi 1999, pp. 718-720. 37 col. II ll. 26-36; also Prince 2015, 565-567; Luz 2015, 302 n. 37; Brancacci 2004, 226-232; Guida 1989, no. 18 2T; Decleva-Caizzi 1966, fr. 192 \& n. There is a play

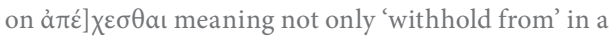
moral sense, but also 'withdraw/keep my distance' in the context of the sea-battle allegory.

38 Although Guida reads [ $\check{\varphi} \varphi \eta \theta \alpha \lambda]$

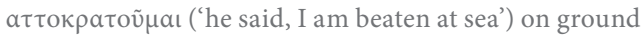
of line spacing, digital magnification of Comparetti 1910 Tavola III (Luz 2015, n. 37) justifies: Gallo 1980, 239; Decleva-Caizzi 1966, fr. 192; SSR V 175.

39 He cites the two anecdotes in reply to the claim: 'that you maintain that they (philosophers)

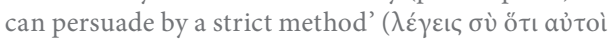

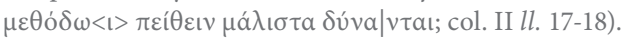

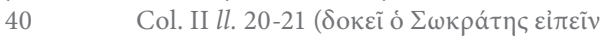

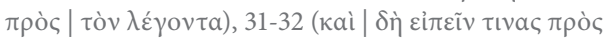
A $v \tau \tau \iota \sigma \theta \dot{\varepsilon} \mid v[\eta)$. In the case of Alcibiades, it explicitly stated that his nocturnal activities were detrimental to his becoming a better man, but similarly Antisthenes' favourite sought a dinner from which the philosopher would withhold himself.

41 Cf. col. II ll. 25-26 'they unravel by night' (זฑ̀v

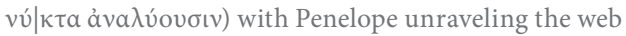

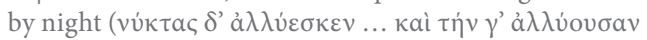
$\dot{\varepsilon} \varphi \varepsilon \dot{v} \rho \circ \mu \varepsilon v)$ while the suitors ( $\mu \nu \eta \sigma \tau \tilde{\eta} \rho \varepsilon \varsigma)$ party below (Od. 2.105-109; 19.150; 24.140-145). Allegorically, Alcibiades and his nocturnal suitors unravel the web of his studies completed 'over such a long a time' (ll. 23-24:

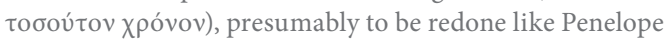

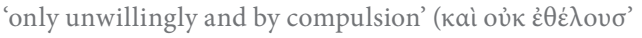

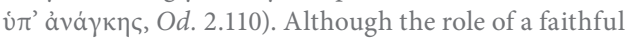
Penelope would suit Socrates, here he presumably stands in the wings like Odysseus.

$42 \quad$ Formally speaking, not every deipnon was a symposium, but since the latter often included a preliminary deipnon (Xen. Symp. II 1; Plat. Symp. 174a), not too fine a distinction should be drawn between them in a Socratic context.

43 They thrived successfully about him

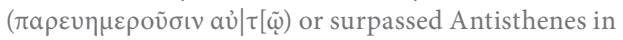

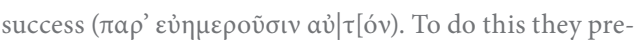
sumably plied the lad not only with 'a fish supper' at the deipnon stage, but also with wine at the symposion stage. The anecdote is thus a sign that Antisthenes disapproved of both the event itself and their success with his ward. $44 \quad$ Since he loved the lad ( $\dot{\varepsilon} \rho \tilde{a} v)$ and had rival anterastai, he must have been a sort of erastes himself, albeit on a philosophical level rather than in a physical sense (Prince 2015, 565-567).

45 On the unity of both anecdotes, see: Brancacci 2004, 228; Luz 2015, 310 and n. 74.

46 Partly in Plutarch: that Alcibiades slipped away (to other suitors) although still pursued by Socrates (Vit. Alc. 6). In his lost Alcibiades, Antisthenes charges him with having been the 'common' eromenos of the whole of Greece (SSR VA fr. 199), which is less praise of his external virtue (Prince 2015, 682) as a damnation of his sexual appetite and impropriety (Wohl 2002, 130-132, 147-149, 163-164).

47 In Papyr. Flor. 113, the four Socratic analogies immediately preceding the two anecdotes (col. II $l l$. 1-17) do discuss success as well as failure so that it is feasible that our two anecdotes were also followed by discussion of the success of philosophical persuasion in the following lacuna if not in the sympotic discussion of col. III 12-13.

48 Prince 2015, t. 175 pp. 565-567; SSR II 1990, VA 64; Decleva-Caizzi 1966, fr. 192 \& n.; also the papyrological evidence in Guida 1989, no. 18 2T.

49 Luz 2015, 310 n. 74; Brancacci 2004, 226-232

(cf. D.L. vi.13; SSR VA 134, 106).

50 Kahn 1998, 30-31 in affinity with Xenophon, rather than influencing him proper.

51 SSR VA 93; Prince 2015, 326-327. In one of Antisthenes' Hercules compositions, the hero is addressed by Prometheus following a scene describing his conversation with Chiron and Achilles with Antisthenes' interrupting the discussion of both scenes in order to make autoptic remarks of his own (Luz 1996, 89-103). 52 Kahn 1998, 32 on the discrepancy between his opening claim to have been present (paragenomenos) at it (Symp. 1. 1-2), but is not mentioned again. Cf. also Xen. Oec. I. 1 ('I once heard (Socrates) speak'); Mem. II. 1; in other places he merely 'knows' (viz. had heard about) what Socrates said (III.1).

$53 \quad 1$. Socrates has actually taught $(\delta \mathrm{t} \delta a ́ \xi \omega$. Alcibiades virtue (col. II l. 25; cf. D.L. vi. 10: virtue is

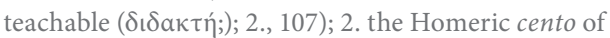
Penelope's web used as a philosophical analogy for the unraveling of arguments, not in the sense of their solution, but in pupil's dissuasion. See also: Brancacci 2004, 228; Luz 2015, 304 n. 49).

$54 \quad$ DL vi. 17 (On Helen and Penelope), 18 (On

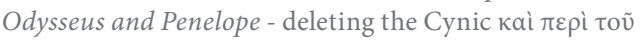
кvvóc; Prince 2015, 124; Goulet-Cazé 1999, 699 n. 5, 701 n. 2). On his moral criticism of Alcibiades in a Socratic dialogue: SSR VA 198-202; Luz 2014, 176-177.

55 Antisthenes' criticism of Alcibiades excludes him as Antisthenes' favourite in the second anecdote. 
Elsewhere, he contrasts his physical beauty (SSR VA198; Prince 2015,679) to the ugliness of his soul: if Achilles had not been of that sort (scil. beautiful in soul), he would not have been truly beautiful (Luz 2014, 184 n. 87).

$56 \quad$ His Hercules contained episodic conversations between Hercules and Prometheus, Chiron and Achilles (Prince 2015, 143-145; Luz 1996, 89-103).

57 Prince 2015, 567-568; Brancacci 2004, 226); as a 'middle', 'have mastery over the sea' (Gallo 1980, 239), it is unsupported.

58 Storey 2011, I 438 fr. 2; PCG V p. 9-10 Demetrius I fr. 2. Note Demetrius' negative 'no longer beaten at sea' is comparable with the reading of the anecdote as a negative 'not beaten at sea' rather than Guida's positive (above, n. 38).

59 Brancacci 2004, 230-231; Guida 1989, 239.

Thus, in contrast to Athens, Antisthenes is 'not defeated at sea' and 'the walls of his soul are unshaken and unbro-

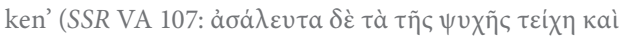
à $\rho \alpha \gamma \tilde{\eta}) ; 134$ (DL VI. 13).

$60 \quad$ PCG V p. 9-10 Demetrius I fr. 3: 'to reestablish the demos free and untrammeled by tyrants'. Dating it to when sad memories of Athens' defeat had faded (Storey 2011 I 436) overlooks this line glorifying the return of the democracy. 